\title{
Skriftuurlike grondslae vir die gereformeerde teologiese etiek
}

\author{
P.J. de Bruyn \\ Departement Dogmatologie en Ekklesiologie \\ Potchefstroomse Universiteit vir $\mathrm{CHO}$ \\ POTCHEFSTROOM
}

\section{Scriptural foundations for Reformed theological ethics}

The discipline of ethics is concerned with the question as to whether interpersonal acts are good or bad. Subsequent questions concerning who or what determines whether an act is good or bad, lead one toward the underlying Scriptural principles of Reformed theological ethics. These underlying principles are the following: the creation of all things by God and his dominion over everything; sin, the covenant of grace, redemption from sin by Christ, the ascension and reign of Christ, the descent and work of the Holy Spirit, the second coming of Christ; the Word (and especially the law) of God as norm for the life of man. Scripture provides clear norms regarding matters such as murder, adultery and theft, but there are no specific norms for ethical questions such as abortion, euthanasia, family planning, etc. This fact gives rise to the distinction between revealed, concretised and contingent norms.

\section{Inleiding}

\subsection{Probleemstelling, doel en metode}

Die teologiese etiek is in die Skrif gefundeer (NGB art. 7; HK Sondae 3444). Dit bring noodwendig mee dat daar in die etiek ' $n$ beroep op bepaalde uitsprake in die Skrif gedoen moet word ter stawing van sekere standpunte (vgl. Buys, 1988:426-445). Op sigself is dit vir die gelowige 'n vanselfsprekende saak. Wat wel 'n probleem is, is die wyse waarop die beroep op die Skrif gedoen word. So het Kuitert in 1970 (Kuitert, 1970:71) maar ook heel onlangs $(1992: 288,289)$ ernstig beswaar gemaak teen die willekeurige wyse waarop daar soms in die etiek van Skrifuitsprake gebruik gemaak word. Hoewel sy beswaar binne die raamwerk van sy eie teologie 
gesien moet word, kan nie ontken word nie dat daar in die verlede ook gereformeerde teoloë was wie se Skrifberoep in die etiek neergekom het op 'n verdraaiing van die inhoud van die Skrif om by 'n heersende standpunt aan te pas (vgl. De Klerk, 1936:4 se hantering van 1 Kor. 7:5). Dit dwing die Christen om opnuut te vra wat die Skriftuurlike grondslae is wat moet dien as basis en kaders vir die korrekte beroep op die Skrif met die oog op die beantwoording van die Christen se etiese vrae. Daarom het hierdie artikel ten doel om die betrokke grondslae of uitgangspunte aan te dui waarsonder die gereformeerde teologiese etiek nie kan funksioneer nie. Die grondslae sal heilshistories bepaal word en in die lig daarvan sal die aard van die etiese norme aangedui word.

\subsection{Etiek}

Waaroor gaan dit in die etiek?

Die etiek het te doen met die vraag of intermenslike handelinge goed of sleg (kwaad) is (Rothuizen, 1973:31; Van Wyk, 1986:2; Velema, 1990:9).

Drie opmerkings ter toeligting is hier van belang.

* Soms word gesê dat dit in die etiek ook gaan om die reg of verkeerd van 'n intermenslike handeling (vgl. Van Wyk, 1986:2). Die probleem waarmee ' $n$ mens hier te doen kry, is dat die onderskeid tussen reg en verkeerd ook ' $n$ juridiese onderskeid is. Mense heg egter in hulle daaglikse spraakgebruik en ook in etiese geskrifte dermate 'n etiese konnotasie daaraan dat die onderskeid tussen goed en sleg (kwaad) aan die een kant en reg en verkeerd aan die ander kant as wisselvorme gebruik word. En in 'n sekere sin is hierdie oorvleueling van begrippe verstaanbaar omdat ' $n$ mens in albei gevalle te doen het met gehoorsaamheid of ongehoorsaamheid aan 'n wet-die wet van God.

* Die vraag is verder of 'n mens se verhouding tot God ook as 'n etiese verhouding beskou kan word. Hoewel Van der Walt (1971: 225-229) en Van Wyk (1986:3) meen dat dit wel die geval is, toon Stoker $(1941: 58,59)$, Heyns $(1982: 10,31)$ en andere tereg aan dat die mens se verhouding tot God wel etiese dimensies het, maar dat dit primêr 'n godsdienstige verhouding is wat baie wyer en omvattender is as ' $n$ etiese verhouding.

* Hoewel gesê is dat etiek met die handelinge van mense te doen het, mag daaruit nie afgelei word dat die etiek nie met die gesindheid en 
gedagtes van die mens te doen het nie. Nie slegs die tiende gebod van die Dekaloog nie, maar al die ander gebooie impliseer dat ook die mens se denke en besinning eties beoordeel kan word (Matt. 5:27, 28; 1 Joh. 3:15).

As die vraag gestel word: wie of wat bepaal of iets goed of sleg is, gaan soek die gelowige die grondslae vir die gereformeerde teologiese etiek in die Skrif.

\section{Grondslae vir die gereformeerde teologiese etiek}

\subsection{Skepping en regering}

In die Nederlandse Geloofsbelydenis (art. 14) word bely:

Ons glo dat God die mens uit die stof van die aarde geskep het; Hy het hom volgens sy beeld en gelykenis gemaak en gevorm, dit wil sê goed, regverdig en heilig, sodat hy met sy wil in alles met die wil van God kon ooreenstem.

Die goed-wees van die mens word hier sonder twyfel ook bepaal daardeur dat sy wil met die wil van God ooreenstem. En die feit dat hier gepraat word van die wil van God as die bepalende faktor waarmee die wil van die mens aanvanklik ooreengestem het, vestig onteenseglik die aandag daarop dat God nie net die Skepper van die mens is nie, maar ook die Koning, die soewereine Regeerder wat bepaal wat goed en sleg, reg en verkeerd is (vgl. HK antw. 124).

Hierdie feit dat God sowel Skepper as Regeerder is, kom reeds in Genesis 1 en 2 duidelik na vore. Daar word immers nie net melding gemaak van die feit dat God die mens geskep het nie, maar ook van God se regering as Hy bepaalde opdragte aan die mens gee om uit te voer. In hierdie verband moet veral na die proefgebod (Gen. 2:16,17) verwys word. Daarin toon God duidelik dat sy wil die maatstaf vir die goed of sleg van die handelinge van die mens is. As die mens aan God se wil gehoorsaam is en nie van die betrokke boom se vrugte eet nie, tree hy reg en goed op, want dan stem sy wil en handelinge ooreen met die wil van God. Is hy egter ongehoorsaam en verwerp hy die wil van God, tree hy verkeerd en sleg op.

Hierdie besondere verband tussen God se skepping en regering, tussen God as Skepper en Koning, kom ook elders in die Skrif duidelik na vore. Volgens Jesaja 43:15 sê die Here: "Ek is die Here julle heilige God, die Skepper van Israel, julle Koning". 
Die mens se onderwerping aan die regering van God moet in die besonder tot openbaring kom as hy in God se skepping gaan werk volgens die kultuuropdrag wat hy van God ontvang het (Gen. 1:28; 2:15).

Die skepping en regering van die soewereine God kan dus as die eerste grondslag van die gereformeerde teologiese etiek beskou word.

\subsection{Die sondeval}

Dat die sondeval 'n ingrypende invloed op die hele lewe van die mens gehad het, is heeltemal verstaanbaar as in gedagte gehou word wat sonde werklik is. Sonde is na sy wese moedswillige ongehoorsaamheid aan God (Gen. 3:1-6); dit is 'n oortreding van die wet van God en daarom wetteloosheid (1 Joh. 3:4); dit is hoogmoed en verwaandheid (Gen. 3:5; 1 Tim. 3:6). Calvyn (Inst. 2.1.4, 1986:355) beskou ongeloof as die wortel van die sonde. Volgens Van Genderen en Velema (1992:366) word al bogenoemde aanduidings van die sonde saamgevat in die woord verbondsverbreking.

Deur die sondeval het die mens die bevel van die soewereine God geminag en die verkeerde en slegte gekies. Die Nederlandse Geloofsbelydenis artikel 14 stel dit so:

Hy het immers die gebod van die lewe wat hy ontvang het, oortree en homself deur die sonde losgeskeur van God, wat sy ware lewe was; so het hy sy hele natuur verderf en daarmee die liggaamlike en geestelike dood verdien.

Die aanduiding dat die mens deur sy sonde "sy hele natuur verderf" het, is in hierdie verband van besondere belang, veral as dit in verband gebring word met die verstand en die hart van die mens wat wel onderskei maar nie geskei mag word nie.

Die verstand van die mens is verduister (Rom. 1:21; Ef. 4:18; 1 Pet. $1: 14)$. Ook ten opsigte van sy verstand is die woorde van die Nederlandse Geloofsbelydenis artikel 14 van toepassing: "Hy het ... al sy voortreflike gawes wat hy van God ontvang het, verloor." In die plek van die voortreflike gawes het daar, wat sy verstand betref, "blindheid, verskriklike duisternis ... en verdorwenheid van verstandelike oordeel" gekom (Dordtse Leerreëls, $3 / 4,1$ ). Die gevolg is dat hy uit homself nie meer weet wat goed en sleg, reg en verkeerd is nie. Ridderbos (1959:45) stel dit so:

De zonde brengt haar eigen bederf op allerlei wijze met zich. Het hart, dat zich in onverstand van God afwendt, geraak steeds meer het spoor bijster, 
niet alleen ten aanzien van God, maar ook van het menselijk leven zelf. (Vgl. Matt. 6:23.)

Selfs wanneer die mens daarvan oortuig is dat hy eties die goeie doen, doen hy heel dikwels in werklikheid die slegte (Matt. 16:22-23).

Maar ook die hart van die mens is deur die sonde aangetas. Voor die sondeval was hy "in sy wil en hart ... met geregtigheid toegerus, en sy hele gesindheid was suiwer" (Dordtse Leerreëls, $3 / 4,1$ ). Na die sondeval het in die plek daarvan gekom "boosheid, rebellie en hardheid van sy wil en hart sowel as onsuiwerheid van sy hele gesindheid" (Dordtse Leerreëls, 3/4, 1). Dit is van ingrypende betekenis omdat die gesindheid van die hart die mens se hele lewe bepaal (Spr. 4:23).

Deur die sonde het die mens innerlik onwillig geword om te doen wat goed en reg is volgens die wil van God, hy het ongehoorsaam aan God geword, hy het 'n rebel teen God geword.

\subsection{Die genadeverbond}

Direk na die sondeval beloof God in die moederbelofte dat Hy self vir die mens verlossing sal bewerk (Gen. 3:15). Hy begin dit realiseer deur uit Abraham vir Hom 'n volk te bou uit wie die Verlosser gebore sal word. Met die oog daarop rig Hy met Abraham die genadeverbond op (Gen. 17). Daarvolgens beloof $\mathrm{Hy}$ om vir hom en sy nageslag 'n God te wees wat impliseer dat Hy vir hulle verlossing van sonde sal bewerk, maar Hy eis van hulle om sy gebooie uit dankbaarheid vir sy genade te gehoorsaam.

Omdat die mens vanweë die sonde nie meer suiwer geweet het wat die wil van God is nie, formuleer God self sy wil vir hulle deur die Tien Gebooie as sedewet te gee (Eks. 20; Deut. 5). Wat die mens voor die sondeval as intuitiewe kennis van God ontvang het, word nou as 'n voorskrif van buite af aan hom gegee.

Tog moes Israel nooit probeer het om deur wetsonderhouding die breuk met God te heel en so sy eie saligheid te bewerk nie. Dit kon nie húlle of enige ander sondige mens ooit bewerk nie. Dit was ook nie die bedoeling van die wet nie. Maar uit dankbaarheid vir die feit dat God vir hulle 'n God wil wees, en in die besonder vir die verlossing uit Egipte en die uiteindelike genadige verlossing van sondes wat Hy vir hulle sou bewerk, moes hulle die gebooie van die Here met vreugde onderhou het (vgl. Janse van Rensburg, 1991:157-160). 
Hierdie motivering vir die onderhouding van die gebooie van God het die grootste deel van Israel egter nie verstaan nie of mettertyd vergeet. Daarom word daar in die loop van die geskiedenis by hulle in hoofsaak tweërlei houding teenoor die wet van God aangetref. Enersyds verdwyn hulle dankbaarheid teenoor God se genade aan hulle en dit lei daartoe dat hulle God se gebooie minag en daaraan ongehoorsaam is. Gevolglik word hulle as straf daarvoor in ballingskap weggevoer (2 Kon. 17:7-18; Neh. 1:6, 7; Dan. 9:4-19). Andersyds het die feit dat hulle die indikatief van God se genade misken het, hulle daartoe gebring om van die imperatief 'n afgod te maak. Sodoende het hulle uiteindelik daartoe gekom om deur eie wetsonderhouding hulle saligheid te probeer uitwerk (vgl. Luk. 13:14-17). Hulle het eintlik net die wet van God raakgesien, maar nie die God van die wet nie.

\subsection{Die verlossing deur Christus}

Uiteindelik vervul God sy belofte en stuur Hy sy Seun wat as borg deur sy passiewe en aktiewe gehoorsaamheid vir sy ware volk versoening doen by God en die weg na die ewige lewe baan (Van Genderen \& Velema, 1992: 475; Verkuyl, 1992:231-234). Deur sy passiewe gehoorsaamheid het Hy die straf van God vir die sonde en die wetsoortreding van die mens gedra (Jes. 53:5; vgl. Hand. 8:30-35). Deur sy aktiewe gehoorsaamheid het Hy in die plek van die mens die wet van God volmaak vervul (Matt. 5:17).

Hierdie borgtogtelike gehoorsaamheid van Christus het vir die etiek veral twee betekenisse. Eerstens, wie nog soos baie Jode tydens Christus se omwandeling op aarde, probeer om deur eie wetsonderhouding versoening met God en hulle eie saligheid uit te werk, is op 'n doodlooppad. Vir hulle sê Paulus dat Christus die einde van die wet is (Rom. 10:4; vgl. Ridderbos, 1959:233; 1966:167, 314). Christus het God se volle oordeel oor die oortreding van die wet gedra sodat dié wat voor God geregverdig wil word, dit nie meer deur wetsonderhouding kan doen nie maar slegs deur die geloof in Christus daaraan deel kan kry. Maar daarmee - en dit is die tweede betekenis - is die onderhouding van die wet nie opgehef nie. Die eise van die wet bly nog geld - dog nie as verlossingsmiddel nie, maar as reël van dankbaarheid, soos Paulus in verskeie uitsprake duidelik aantoon (Rom. 13:8-10; 1 Kor. 7:19; 9:21; Gal. 6:2; vgl. ook Büsser, 1963:163-165; Velema, 1987:157; Janse van Rensburg, 1991:87-89). En as 'n mens werklik uit die geloof lewe, sodat die lewe vir jou Christus is (Gal. 2:20; Fil. 1:21) en dieselfde gesindheid in jou is wat in Christus was (Fil. 2:5), 
sal jy ook toenemend in staat wees om te kan doen wat Hy vra. Die mens sal meer bereid wees om sy vyande lief te hê as hy daagliks lewe uit die gelowige verwondering dat God sy liefde in en deur sy Seun teenoor hom betoon het "toe ons nog vyande was" (Rom. 5:10; vgl. Overduin, 1959:34, 35; Lapide, 1984:18).

\subsection{Christus se hemelvaart en koningsheerskappy}

Christus het opgevaar na die hemel om Hom daar te betoon as Hoof van sy Christelike kerk deur wie die Vader alles regeer (HK antw. 50). Christus, aan wie alle mag in die hemel en op die aarde behoort (Matt. 28:18), regeer sy kerk vanuit die hemel deur sy Woord en Gees (HK antw. 123). Vir die etiek is dit belangrik dat die mens moet weet dat hy hom aan hierdie regering van die Kurios moet onderwerp (Stam, 1950:52; Bos, 1993: $426,427)$. Hy moet sy lewe laat beheers deur die wil van sy verhoogde Here (1 Kor. 15:25; Kol. 3:1-17). Uit homself is die mens nie daartoe in staat nie. Daarom gee God self sy Heilige Gees aan hom om dit vir hom moontlik te maak om die wil van sy koning te doen.

\subsection{Die uitstorting van die Heilige Gees}

Op Pinksterdag het God sy Heilige Gees uitgestort op sy kerk (Hand. 2). Deur die Heilige Gees word die mens in wie Hy woon en werk aan Christus verbind sodat hy deel kry aan Christus se soenverdienste, aan sy borgtogtelike betaling van skuld weens die mens se wetsoortreding en aan sy volmaakte gehoorsaamheid (Joh. 14:26; 16:13, 14; Rom. 5:5; Gal. 3: 14; vgl. Van Wyk, 1983:5; De Bruyn, 1990:33; Ridderbos, 1992:189). As die Heilige Gees die mens aan Christus verbind, doen Hy dit deur wedergeboorte, geloof en bekering in hom tot stand te bring (Joh. 3:5; Ef. 2:8; Fil. 1:29).

Wat die Here deur die Heilige Gees met sy wet aan die mens doen, is vir die etiek van besondere belang. Soos reeds aangedui (vgl. 2.2) is, het die sonde tot gevolg gehad dat die wet van God, deur die verduistering van die mens se verstand en deur sy onwilligheid om dit te gehoorsaam, tot 'n baie groot mate uit die lewe van die mens verdring is. Maar met die uitstorting van die Heilige Gees gebeur daar iets heel besonders. In sy groot genade skryf God weer sy wet op die harte van sy kinders en lê dit in hulle gedagtes vas (Jer. 31:33). Daarom kan die mens nou weer die waarde van God se wet verstaan (Ps. 19, 119). Dit is egter nie al nie, want Hy verander deur sy Gees ook hulle gesindheid en maak hulle gewillig om sy wet 
te onderhou. So vervul Hy sy belofte deur die profeet Esegiël: "Ek sal my Gees in julle gee en Ek sal maak dat julle volgens my voorskrifte leef en my bepalings gehoorsaam en nakom" (Eseg. 36:27).

Wat die Heilige Gees in hierdie verband doen, word op treffende wyse in die Dordtse Leerreëls $(3 / 4,11)$ soos volg beskryf:

Deur die kragtige werking van dieselfde Gees wat die wedergeboorte skenk, dring Hy ook deur tot in die binneste dele van die mens, open Hy die geslote hart, versag Hy wat hard is en besny Hy wat onbesnede is. In die wil stort Hy nuwe eienskappe in en maak die wil, wat dood was, lewend; wat sleg was, goed; wat onwillig was, gewillig en wat ongehoorsaam was, gehoorsaam. Hy beweeg en versterk die wil sodat dit, soos 'n goeie boom, vrugte van goeie werke kan dra.

Die Heilige Gees leer die mens dus om die waarde van die wet te verstaan en om die betekenis daarvan te begryp. Verder maak die Gees die mens gewillig om die wet uit dankbaarheid te onderhou.

Deur hierdie siening word duidelik standpunt ingeneem teenoor diegene wat beweer dat as die Gees 'n mens lei, jy die wet nie meer nodig het nie (Nygren, 1952:275, 276; Brunner, 1956:129; Kemp, 1992:163). Uit die Skrif is dit immers duidelik dat die gawe van die Gees die binding aan die wet nie ophef nie. So skryf Paulus in Romeine 8:4: "Nou kan ons aan die eise van die wet voldoen, óns wat ons lewe nie deur ons sondige natuur laat beheers nie, maar deur die Gees." (Vgl. ook Gal. 5:22, 23, 25.) Uit hierdie uitspraak is dit volgens Ridderbos (1966:313) duidelik dat "het werk van de Geest bestaat juist mede in het uitwerken van de wet in het leven der gelovigen". Die wet is heilig en geestelik (Rom. 7:14) en kan daarom nie teenoor die Gees gestel word nie. Die wet word deur die Gees nie oorbodig gemaak nie maar eerder daardeur bevestig. Om jou deur die Gees te laat lei, bestaan onder andere daarin dat die mens opnuut leer om te onderskei en te bepaal wat die wil van God is, met ander woorde wat vir Hom goed en aanneemlik en volmaak is (Rom. 12:2). Soortgelyke kwalifikasies word elders (Rom. 7:12) aan die wet verbind (Ridderbos, 1966: 313).

\subsection{Die wederkoms van Christus}

Vir die etiek is dit ook uiters noodsaaklik om die eskatologiese perspektief nie uit die oog te verloor nie. Waar 'n mens met 'n wet en met oortreding van die wet te doen het, is dit eintlik vanselfsprekend dat oor hierdie wetsoortreding geoordeel sal moet word. Die Skrif stel dit duidelik dat daar 'n 
dag van afrekening kom - die oordeelsdag. Paulus sê: "Ons moet immers almal voor die regterstoel van Christus verskyn, sodat elkeen kan ontvang volgens wat hy tydens sy aardse lewe gedoen het, of dit nou goed was of kwaad" (2 Kor. 5:10; vgl. ook Rom. 14:10,11; Op. 20:12). Volgens Grosheide (1959:154) lê Paulus hier 'n verband tussen die aardse lewe en die oordele wat kom en hy doen dit om gelowiges en ongelowiges te waarsku.

Op dié dag sal God self ook oordeel of dit wat elke mens gedoen het, eties goed of eties kwaad (sleg) was (vgl. Grosheide, 1959:152). In die woorde van Berkouwer (1961:201) staan alle dinge met die wederkoms van Christus onbedek voor die troon van die Lam. Hier word die slegte nie meer goed genoem nie en die goeie nie sleg nie; die duisternis word nie meer as lig voorgestel en die lig as duisternis nie, of wat bitter is as soet en wat soet is as bitter nie, omdat aan alle verleuening van die lewe 'n einde, 'n radikale einde kom. Dit is die onontwykbaarheid van die wederkoms.

Vir die ongelowige en goddelose wat die wet van God geminag het, sal die oordeelsdag die begin van die ewige straf wees (Op. 21:8). Die gelowige gaan die oordeelsdag egter met dankbaarheid en blye verwagting tegemoet, veral om twee redes. Eerstens weet hy dat hoewel hy self vanweë sy wetsoortreding diep skuldig voor die Regter sal staan, hy vrygespreek sal word omdat Christus self vir al sy wetsoortredings ten volle betaal het. Die Skrif stel dit immers duidelik dat daar "nou geen veroordeling (is) vir dié wat in Chrisus Jesus is nie" (Rom. 8:1). Tweedens weet hy dat hy op dié dag van God 'n loon sal ontvang vir die goeie wat hy gedoen het (Matt. 5:12; Heb. 11:26). Dit is wel 'n genadeloon (Luk. 17:10), maar dan tog 'n loon.

Dit moet die gelowige nog des te meer motiveer om die wet uit dankbaarheid te onderhou (vgl. Janse van Rensburg, 1991:132-137).

\subsection{Die Woord en in die besonder die wet van God as norm vir die mens}

\subsubsection{God se Woord en God se wet}

In die Christelike etiek, waarin daar oor 'n persoon se gesindheid en handelinge geoordeel moet word, het 'n mens veral te doen met die wet van God soos dit in die Tien Gebooie geformuleer is as konkretisering van die dubbele liefdesgebod (vgl. 2.8.3.4). Tog beteken dit nie dat die Dekaloog van die res van die Skrif losgemaak kan word nie. Wat in punte 2.1 tot 
2.7 gesê is, toon duidelik aan dat dit juis nie gedoen kan word nie. Die wet moet in die etiek gehanteer word soos dit ingebed lê in en toegelig word deur die geheel van die Woord. Van Wyk (1983:35) gee Calvyn se siening in hierdie verband soos volg weer: "In 'n sekere sin trek die ganse Heilige Skrif egter in die Tien Gebooie saam. Die ganse Skrif is niks anders as 'n eenvoudige verklaring van die wet nie."

\subsubsection{Kan die wet van God 'n norm genoem word?}

Wat is die verskil tussen 'n wet en 'n norm? Dit is belangrik om daaroor te besin aangesien dié twee woorde dikwels as sinonieme gebruik word. Sonder om dié woorde semanties te beoordeel en teen mekaar op te weeg, word hier aangesluit by Heyns $(1982: 178,179)$ wat "die term wet gebruik vir die fisiese gebeure in die natuur - waarby die fisies-biologiese aspek van die menslike bestaanswyse uiteraard ingesluit is". So 'n wet tref 'n mens aan in die bloedsomloop, die klop van die hart, swaartekrag, ensovoorts. Hierdie wette het 'n dwingende karakter en is in werklikheid onoortreebaar, hoewel dit tog - of sommige daarvan - tot 'n mate oorwinbaar is.

Daarteenoor dui 'n norm nie die feitelike verloop van gebeure aan nie maar beskryf hoe dit behoort te verloop. Heyns (1982:179) stel dit so:

Met sy dringende karakter is die norm dus oortreebaar, want hy veronderstel en appelleer op die moontlikheid van keuse, insig, voorkeur, beredenering en beslissing by die mens. Die oortreebaarheid van die norme mak die mens egter nie ten opsigte van sy gehoorsaamheid aan norme volledig vryblywend, asof dit 'n saak van onverskilligheid is nie. As leidinggewende en koersaanduidende rigsnoere vir die voltrekking en beoordeling van menslike aktiwiteite, is norme ook verpligtinge wat die mens opgelê word.

As dit die betekenis is wat aan norme geheg word en norme dus meer is as "veranderlike reëls" (Buys, 1989:2), dan is dit duidelik dat daar wel van die Tien Gebooie en ander voorskrifte in die Woord van God as norme gepraat kan word. Dit is ook die siening van Velema (1990:49), want hy sê: "Christelijke ethiek vind haar norm in de wet van God. Jezus Zelf is ons daarin voorgegaan." Douma (1990:43) gee 'n soortgelyke uitspraak.

\subsubsection{Die kenmerke van God se wet as norm}

Die aandag word hier gevestig op slegs enkele kenmerke of wesenseienskappe van veral die Dekaloog wat spesifiek vir hierdie studie van belang is. Elders is dit meer volledig behandel (vgl. De Bruyn, 1991:199-216). 
P.J. de Bruyn

\subsubsection{Die wet as openbaring van God se wesenseienskappe}

Hoewel dit vanselfsprekend is, is dit tog opvallend hoe duidelik God se wese in sy gebooie geopenbaar word. Omdat God na sy wese liefde is, eis Hy van sy kinders om Hom bo alles en ook mekaar lief te hê ( 1 Joh. 4:716; Matt. 22:35-40). Omdat Hy na sy wese 'n God van waarheid is en nie kan lieg nie (Ps. 31:6; vgl. Num. 23:19; 1 Sam. 15:22; Tit.1:2), eis Hy ook van sy verbondsvolk om lewende en sprekende getuies van die waarheid te wees en nie te lieg nie (Eks. 20:16; Jes. 63:8; Ef. 4:25; Op. 21:8). Die implikasie hiervan word deur Calvyn (Inst. 2.8.51, 1986:553) soos volg weergegee:

Nou kan ons maklik oordeel wat die doel van God se wet in sy geheel is, naamlik die vervulling van geregtigheid sodat dit die mens se lewe in vergelyking met die voorbeeld van God se reinheid kan vorm. Want God het sy eie aard (my kursivering) daar so afgeteken dat as iemand met sy dade alles sou uitbeeld wat daarin gebied word, hy in 'n sekere sin in sy lewe aan die beeld van God uitdrukking sou gee.

Die Latynse woord ingenium wat hier met aard vertaal is, word deur Beveridge (Calvyn, 1845:483) met character vertaal.

Bogenoemde siening van Calvyn word ook gesteun deur Bahnsen (1985: 192) wat sê:

The law declares the character of God and so reveals his glory. The kind of lifestyle and attitudes which the Lord requires of His people tells us, of course, what kind of God He is.

Ook Kaiser $(1983: 29,30)$ en Higginson, (1988:69) lê 'n nou verband tussen die wet en die wese van God.

Dit beteken dat 'n mens in God se wet op 'n heel besondere wyse met God self te doen het. Vanselfsprekend is dit vir die lewe volgens God se wet en vir die beoordeling van mense se lewens aan die hand van God se wet van die allergrootste belang.

\subsubsection{Die preskriptiewe aard van die wet}

Die wet van God het sonder enige twyfel duidelik 'n preskriptiewe aard. Dit sê uitdruklik aan die mens wat hy behoort te doen en nié behoort te doen nie (Van Wyk, 1986:5; Kaiser, 1983:28-29).

Omdat God die Skepper en Verbondsgod van sy volk is (Jes. 43:1; 45:912), het Hy ook die reg om aan hulle voor te skryf wat om te doen en hoe om te lewe. Hy doen dit ook deur sy voorskrifte in 'n persoonlike vorm te 
giet. Telkens word die tweede persoon enkelvoud $j y$ gebruik: " $J y$ mag nie..." Hierdie jy/jou het 'n kollektiewe en individuele betekenis. Hy rig Hom tot die volk as geheel maar ook tot elke lid van die volk afsonderlik (Douma, 1985:20).

Die preskriptiewe aard van die Tien Gebooie blyk ook daaruit dat dit geformuleer is in die vorm van absolute, totalitêre eise. So word in die eerste gebod van die mens geëis om God alleen te dien en eksklusief net aan Hom as die enigste God onderworpe te wees. Naas God mag daar "geen ander gode" wees nie (Eks. 20:3). Dieselfde wyse van formulering word ook in die ander gebooie aangetref (vgl. Van den Berg, 1967?:31). Ook die feit dat $\ll$ ל telkens deur die imperfektum gevolg word, dui 'n absolute verbod aan.

Vanweë die gebrokenheid waarin die lewe van die mens weens die sonde vasgevang is, is hy soms genoodsaak om die gebooie te oortree, byvoorbeeld as hy ter beskerming van homself en/of sy dierbares gedwing word om 'n vyand dood te maak (vgl. ook Matt. 12:10-12). Desondanks word God se wil in die vorm van absolute eise aan die mens voorgehou om te toon dat, al is die oortreding van God se gebooie soms onvermydelik, dit steeds 'n oortreding bly wat die mens moet bring tot verootmoediging voor God (Buys, 1976:9).

Met die erkenning van die preskriptiewe aard van God se wet word die siening van sommige verteenwoordigers van die postmodemisme dat die norm vir die beoordeling van kriminele gedrag by die oortreder self gevind moet word, met beslistheid afgewys (vgl. Boutellier, 1993:91-97).

\subsubsection{Die sinekdogeïese karakter van die Dekaloog}

Die sinekdogee is 'n stylfiguur waarby 'n geheel deur 'n deel aangedui word. 'n Deel woord genoem, maar die geheel word bedoel. 'n Voorbeeld daarvan is die vierde bede van die Onse Vader waarin daar vir "daaglikse brood" gebid word, terwyl die bedoeling daarvan is om van God "alles wat vir die liggaam nodig is" te vra (HK antw. 125).

Calvyn (Inst. 2.8.8, 1986:507) beklemtoon die feit dat die Tien Gebooie sinekdogeïes is as hy sê:

Ons (moet) daarop let dat daar altyd meer is in dit wat die wet gebied en dit wat dit verbied as wat die woorde voorgee ... In feitlik al die gebooie is daar in elk geval soveel duidelike sinekdogeë dat iemand wat die betekenis van 
die wet tot die grens van die woorde daarvan sou wil beperk, bespot sou word. (Vgl. Geesink, 1931:235.)

Die reg om die gebooie as sinekdogeë te beskou, word in die Skrif gevind. Christus self toon byvoorbeeld in Matteus 5:21-22 en 27-28 dat die eise van die gebooie baie verder strek as bloot die letterlike woorde daarvan. Daarom het die opstellers van die Heidelbergse Kategismus die Tien Gebooie ook so verklaar dat hulle vanuit die deel wat genoem word, die groter geheel van God se eis oor die betrokke saak aangedui het.

Hierdie sinekdogeïese karakter van die Tien Gebooie is van groot betekenis vir die Christelike etiek (vgl. De Bruyn, 1993:19, 20). Trouens, in die loop van die geskiedenis het die mens telkens met nuwe verskynsels op etiese gebied te doen gekry, byvoorbeeld geboortebeperking, aborsie, eutanasie, orgaanoorplantings, eksperimente met embrio's, surrogaatmoederskap, omgewingsbesoedeling, ensovoorts. Vir hierdie verskynsels of praktyke hoef daar geen nuwe gebooie gemaak te word of byvoeginge by die Tien Gebooie oorweeg te word nie. Juis die feit dat die gebooie in die vorm van sinekdogeë gegee is, toon duidelik aan dat etiese vraagstukke nie net beoordeel moet word in die lig van die deel wat genoem word nie, maar in die lig van die geheel wat bedoel word. En dit beteken dat selfs die modernste verskynsels of praktyke op etiese gebied beskou kan word as die groter geheel waarop die verskillende gebooie van toepassing is.

\subsubsection{Die wet as konkretisering van die liefdesgebod}

Dit is uiters belangrik om in gedagte te hou dat die Dekaloog ten diepste niks anders is nie as die konkretisering van die gebod van liefde tot God en liefde tot die naaste (Matt. 22:37-40). Dit blyk veral duidelik uit Romeine 13:8-10.

Die rede waarom hierdie saak in die Christelike etiek van soveel belang is, is omdat dit duidelik toon dat dit vir God nie bloot gaan om sekere uiterlike handelinge wat verbied of gebied word nie, maar om 'n optrede wat voortvloei uit liefde tot die naaste. God het die mens eerste liefgehad (1 Joh. $4: 10,19)$. Hierdie liefde van God vir die mens moet deur die mens beantwoord word primêr met liefde tot God (1 Joh. 4:19), maar ook met liefde tot die naaste ( 1 Joh. 4:9-11). Dit is hierdie liefde tot die naaste wat in die daad tot openbaring moet kom. Dwarsdeur die Ou en Nuwe Testament word daar immers geweldige nadruk gelê op die mens se opregtheid van hart in die gehoorsaamheid aan die gebooie van die Here (Ps. 51:12; Spr. 4:23; Jes. 1:11-17; 29:13; Joël 2:12-14; Miga 5:7-8; Matt. 5:27, 28; 15:7, 
8; 22:35-40; 23:1-39, ens; vgl. ook Smedes, 1992:16). Daarom doen die Heidelbergse Kategismus dit ook in sy verklaring van die Tien Gebooie (vgl. Wielenga, 1947:737-738). Daarteenoor word uiterlike etiese goeie handelinge sonder die liefde van die hart ten sterkste deur die Here afgewys en veroordeel (Matt. 6:2; vgl. ook Calvyn, Inst. 2.8.6, 1986:504-506; 3.14.8, 1988:988, 989).

\subsubsection{Soorte norme}

Oor sekere sake soos moord, egbreuk en diefstal is daar vir die mens baie duidelike Skriftuurlike norme gegee. Oor ander sake soos aborsie, eutanasie, geboortereëling, kunsmatige inseminasie, ensovoorts is daar nie sulke uitdruklike norme nie. Dergelike norme moet dus op een of ander wyse bepaal word. Hierdie situasie het daartoe gelei dat daar 'n onderskeid tussen bepaalde norme gemaak is. Hierdie onderskeid raak veral die wyse waarop die norme gegee of geformuleer is en die gesag wat dit dra. Gewoonlik word daar onderskei tussen die volgende drie groepe norme:

* Die geopenbaarde norme.

* Die gekonkretiseerde (gepositiveerde) norme.

* $\quad$ Die kontingente norme. (Vgl. hieroor Duvenage, 1971 ?:1-13; 1972: 212-226; Heyns, 1982:180-187.)

\subsubsection{Geopenbaarde norme}

Geopenbaarde norme is die norme wat God in sy Woord op 'n duidelik geformuleerde wyse as sy wil vir die lewe van die mens gee.

Die gesag van hierdie norme kom volgens Heyns (1982:181) tot openbaring in hulle drievoudige geldigheid. Eerstens is hulle onvoorwaardelik geldig wat beteken dat hulle nie van bepaalde voorwaardes afhanklik is nie. Heyns (1982:181) sê in dié verband:

Ons het hier met kategoriese imperatiewe te doen waarin Gods wil vir die mens se lewe eisend aangekondig word. Daarom mag van hierdie kategoriese imperatief ook geen hipotetiese imperatief gemaak word nie.

So mag daar byvoorbeeld onder geen omstandighede 'n ander god gedien word nie. Tweedens is die norme algemeen geldig. Dit kom daarop neer dat alle mense onder alle omstandighede te alle tye daaraan gehoorsaamheid verskuldig is. Derdens is dit totaal geldig, dit wil sê die totaliteit van die ganse menslike persoon, sy denke, wil, gevoel en al sy geestelike vermoëns moet deur hierdie norme bepaal word. 


\subsubsection{Gekonkretiseerde norme}

Die geopenbaarde norme is bedoel vir die hele lewe van die mens, maar dit is nie sodanig geformuleer dat dit aan die mens sê hoe om in elke etiese probleem wat voorkom op te tree nie. Die Bybel is nie 'n kasuistiese handboek met reëls vir alle moontlike etiese vraagstukke nie. Daarom maak die Bybel ook nie van die gelowige 'n passiewe ontvanger van voorskrifte vir elke situasie nie, maar dit vereis van hom intense inspanning in verskeie opsigte om te wete te kom hoe om op te tree. Dit blyk duidelik uit die Skrif. So skryf Paulus aan die Efesiërs: "Moet daarom nie onverstandig optree nie, maar probeer te wete kom wat die Here wil dat julle moet doen" (Ef. 4:17). En aan die Filippense skryf hy: "Ook bid ek dat julle liefde al hoe meer sal toeneem in begrip en fyn aanvoeling, sodat julle die dinge sal kan onderskei waarop dit werklik aankom" (Fil. 1:9-10; vgl. ook Rom. 12:2). En in Hebreërs 5:14 word gesê: "Vaste kos is vir grootmense, vir mense wat oor insig beskik en wat deur ervaring geoefen is om tussen goed en kwaad te onderskei." (Vgl. oor laasgnoemde teks Troost, 1958:382-364.)

Hoe moet ' $n$ mens dan weet hoe om 'n etiese probleem te beoordeel of hoe om in 'n bepaalde situasie op te tree? Op grond van sy studie van die briewe van Paulus sê Ridderbos (1966:317) dat veral die volgende drie sake vir die gelowige van belang is met die oog op die bepaling van gekonkretiseerde norme:

* Die geloof in Christus.

* $\quad$ Die leiding van die Heilige Gees.

* Die kennis van die wet.

'n Vierde element behoort by hierdie drie by te kom, naamlik:

* Die kennis van die probleem.

Hierdie vier sake dui aan dat daar van die gelowige 'n besondere aktiwiteit gevra word om te kan weet wat God se wil ten opsigte van 'n bepaalde etiese probleem is.

Geloof bestaan uit kennis en vertroue (HK ant. 21). Die kennis-komponent van geloof is so sterk dat Calvyn (Inst. 3.2.3, 1988:711) selfs so ver gaan om te sê: "Geloof is in kennis van God en van Christus geleë." Daarom sal 'n mens geloof ook kan aandui as vertrouende kennis (vgl. Graafland, 1961:24-29). Aangesien dit die geval is, beteken dit dat die gelowige 
met die oog op die konkretisering van norme die Skrif aanhoudend en indringend moet bestudeer omdat dit God se geopenbaarde wil is.

Die leiding van die Heilige Gees impliseer weer die volhardende gebed tot God dat Hy deur sy Gees wysheid, insig en onderskeidingsvermoë sal gee (Ef. 6:17-19; Fil. 1:9-10; Kol. 4:2-4).

Die kennis van die wet sluit in 'n sekere sin aan by wat oor die geloof gesê is, omdat die wet van God ingebed lê in die hele Skrif. In hierdie verband moet die sinekdogeïese aard van die Dekaloog en die feit dat dit 'n konkretisering van die dubbele liefdesgebod is, deeglik in ag geneem word.

Deeglike kennis van die bepaalde probleem met al sy oorsake, gevolge en implikasies is noodsaaklik. As dit ontbreek, kan 'n mens dikwels 'uit die Skrif' 'n norm vasstel wat of irrelevant of heeltemal verkeerd is (vgl. Higginson, 1988:11-34).

Verder moet ten opsigte van hierdie sake die gemeenskap van die heiliges nie vergeet word nie. Een mens het nie al die wysheid en insig in pag nie. Daarom moet kennis geneem word van wat ander gelowiges daaroor sê, hetsy deur gesprekke, hetsy deur geskrifte.

As 'n mens wel 'n norm vir 'n bepaalde etiese probleem geformuleer het, moet dit steeds aan die geopenbaarde norme getoets word. Tereg sê Heyns (1982:183): "Alle verstaan, formulering en realisering van die sekondêre norme, bly dus steeds onderworpe aan die kritiese toetsing en korrigering deur die primêre, geopenbaarde norme."

Die bepaling en formulering van gekonkretiseerde norme is vir die Christen 'n moet, 'n roeping. Hy mag geen draadsitter wees nie (Matt. 6:24; Luk. 9:50). Tog moet hy normbepaling biddend met groot versigtigheid en diepe nederigheid doen. In die verlede is daar immers al norme deur die Christelike kerk geformuleer, byvoorbeeld ten opsigte van seksualiteit, wat eers na eeue geblyk het nie in ooreenstemming met die Woord van God te wees nie (De Bruyn, 1982:19-105).

By die vasstelling van sulke norme behoort daar deeglik kennis geneem te word van die direktiewe by morele keuses wat deur Van Wyk (1991:1735) aangedui word.

\subsubsection{Kontingente norme}

Met kontingente norme word norme vir die hier en nou van 'n konkrete situasie bedoel (Duvenage, 1972:221). 
Die verskil tussen gekonkretiseerde norme en kontingente norme kan soos volg verduidelik word: By gekonkretiseerde norme het 'n mens te doen met 'n bepaalde etiese probleem waarvoor daar geen uitdruklike voorskrif of aanduiding in die Skrif is nie - probleme soos orgaanoorplanting, surrogaatmoederskap, omgewingsbesoedeling, ensovoorts. Christene kan afsonderlik en gesamentlik daaroor besin in die lig van die Skrif en uiteindelik een of meer norme daarvoor formuleer. By kontingente norme het ' $n$ mens gewoonlik te doen met een of meer persone wat 'n morele besluit moet neem in 'n konkrete situasie waarvoor daar geen direkte voorskrif of voorbeeld in die Bybel is nie. Byvoorbeeld, mag 'n onmondige, Engelssprekende, oortuigde en kerklik meelewende Christen in die huwelik tree met 'n onmondige, Afrikaanssprekende naam-Christen wat wel aan 'n kerk behoort maar nie kerklik meelewend is nie, terwyl die twee pa's sterk ten gunste van die huwelik is en die twee ma's sterk daarteen gekant is? In daardie konkrete situasie is dit uiteindelik slegs hulle twee wat voor God afsonderlik en gesamentlik in oorleg met hulle ouers kan besluit of hulle gaan trou en of hulle die verhouding gaan beëindig.

Hierdie erns wat met die situasie gemaak word, beteken geensins die invoering van 'n situasie-etiek soos dié wat deur Fletcher (1967:11-28; 1974:57-145) voorgestaan word nie (vgl. Hebblethwaite, 1982:90, 98). By Fletcher (1974) is die situasie in werklikheid die norm, terwyl die weg wat hier aangedui word, beteken dat die Woord van God in 'n spesifieke situasie steeds die norm bly.

Vir die bepaling van die kontingente norme geld grotendeels dieselfde direktiewe as by die gekonkretiseerde norme. Die subjektiewe betrokkenheid van die persoon of persone wat die norm moet bepaal, hou egter die gevaar in dat nugterheid en objektiwiteit in ' $n$ mindere of meerdere mate in die slag kan bly - 'n toedrag van sake wat 'n verkeerde norm en 'n verkeerde optrede tot gevolg kan hê. En as so 'n norm boonop in 'n baie kort tydsbestek bepaal moet word, word die hele saak net des te meer problematies.

Daarom is die enigste weg vir die Christen wat oor die vermoë wil beskik om die regte kontingente norme te bepaal, om voortdurend die Woord van God in sy geheel te ondersoek. Deel van hierdie ondersoek moet wees om in die lig van eietydse etiese vraagstukke te besin oor die volle betekenis en reikwydte van die wet van God in die lig van die sinekdogeïese aard daarvan en in die lig van die feit dat dit 'n konkretisering van die liefdesgebod is. Maar uit homself kan die mens nie die regte insig kry nie. Daarom 
moet hy by sy Skrifstudie en besinning oor die wet van God bid om die leiding van die Heilige Gees en bewustelik voorkom dat die Heilige Gees in sy lewe weerstaan of bedroef word (Hand. 7:51; Ef. 4:30). So 'n omgang met die Woord onder die leiding van die Heilige Gees sal die Christen help om ' $n$ gelowige sensitiwiteit te ontwikkel wat hom in staat kan stel om by moeilike etiese beslissings bykans intuitief tussen goed en kwaad te onderskei (Troost, 1958:382-384). Met die oog daarop is die ontwikkeling van 'n omvattende Christelike lewenstyl 'n sine qua non. Douma (1993: 41-77), Kamphuis (1991:28-46) en Rietveld (1968:31-90) se aanwysings in hierdie verband verdien ernstige aandag.

By die bepaling van kontingente norme speel die gewete van die Christen 'n besonder belangrike rol (Rom. 2:15; 1 Kor. 8:10). Deur 'n Christelike lewenstyl sal die gewete ook opgeskerp word om in die aanduiding van hierdie norme sy regte funksie te kan vervul (vgl. De Bruyn, 1993:7, 8).

\section{Gevolgtrekking}

Uit die voorgaande is dit duidelik dat die Skrif slegs sy onmisbare plek in die gereformeerde teologiese etıek kan inneem as dit gebruik word op die basis en binne die grondslae wat aangedui is. Daarsonder kan ' $n$ mens die gevaar van 'n willekeurige Skrifberoep wat geen werklike oortuigingskrag het nie en soms selfs misleidend kan wees, nie ontwyk nie.

\section{Bibliografie}

BAHNSEN, G.L. 1985. By This Standard: the Authority of God's Law Today. Tyler (Texas) : Institute for Christian Economics.

BERKOUWER, G.C. 1961. De wederkomst van Christus 1. Kampen : Kok.

BOS, G. 1993. Zondag 48. (In Van de Bank, J.H. et al. Kennen en vertrouwen: handreiking bij de prediking van de Heidelbergse Catechismus. Zoetermeer : Boekencentrum. p. 242-430.)

BOUTELLIER, H. 1993. Solidariteit en slachtofferschap: de morele betekenis van criminaliteit in een postmoderne cultuur. Nijmegen : SUN.

BRUNNER, E. 1956. Der Römerbrief. Kassel : Oncken Verlag.

BUSSER, F. 1963. Die Bedeutung des Gesetzes. (In Coenen, L. red. Handbuch zum Heidelberger Katechismus. Neukirchen - Vluyn : Neukirchener Verlag. p. 159-170.)

BUYS, P.W. 1976. Die botsing van pligte as etiese vraagstuk. Potchefstroom : PU vir CHO.

BUYS, P.W. 1988. Skrifgesag en Skrifberoep in die etiek. Koers, 53(3):426446, Sept. 
BUYS, P.W. 1989. Etiek. Potchefstroom : PU vir CHO. (Dept. Sentrale Publikasies.)

CALVYN, J. 1984 (Inl., Boek 1), 1986 (Boek 2), 1988 (Boek 3), 1991 (Boek 4). [Oorspronklik 1559.] Institusie van die Christelike godsdiens. Vertaal deur H.W. Simpson. Potchefstroom : Calvyn Jubileum Boekefonds.

CALVYN (CALVIN), J. 1845. Institutes of the Christian Religion, Books 1 \& 2. Translated by H. Beveridge. Edinburgh : Calvin Translation Society.

DE BRUYN, P.J. 1982. Voorhuwelikse geslagsgemeenskap: 'n teologies-etiese studie. Potchefstroom : PU vir CHO. (Th.D.-proefskrif.)

DE BRUYN, P.J. 1990. Die gesonde leer. Potchefstroom : Calvyn Jubileum Boekefonds.

DE BRUYN, P.J. 1991. Die verklaring van die Tien Gebooie volgens die Heidelbergse Kategismus. In die Skriflig, 25(2):199-216, Jun.

DE BRUYN, P.J. 1993. Die Tien Gebooie. Midrand : Varia.

DE KLERK, P.J.S. 1936. Die Neo-Malthusianisme - 3. Die Kerkblad, 63 (814):3-4, Aug. 19.

DOUMA, J. 1985. De Tien Geboden 1. Kampen : Van den Berg.

DOUMA, J. 1990. Verantwoord handelen. Kampen : Van den Berg.

DOUMA, J. 1993. Christelijke levensstijl. Kampen : Van den Berg.

DUVENAGE, B. 1971? Ons roeping en ons norme. Potchefstroom : PU vir CHO. (IBC-studiestuk nr. 59.)

DUVENAGE, B. 1972. Die Calvinistiese normeleer. (In De Klerk, W.J., Duvenage, B. \& Van Wyk, J.H. Roeping en werklikheid. Potchefstroom : Potchefstroom Herald. p. 212-226.)

FLETCHER, J. 1967. Moral Responsibility. Situation Ethics at Work. London : SCM Press.

FLETCHER, J. 1974. Situation Ethics: the New Morality. London : SCM Press.

GRAAFLAND, C. 1961. De zekerheid van het geloof: een onderzoek naar de geloofsbeschouwing van enige vertegenwoordigers van reformatie en nadere reformatie. Wageningen : Veenman.

GEESINK, W. 1931. Gereformeerde Ethiek 1. Kampen : Kok.

GROSHEIDE, F.W. 1959. De tweede brief aan die kerk te Korinthe. Commentaar op het Nieuwe Testament. Kampen : Kok.

HEBBLETHWAITE, B. 1982. Christian Ethics in the Modern Age. Philadelphia : Westminster Press.

HEYNS, J.A. 1982. Teologiese etiek 1. Pretoria : N.G. Kerkboekhandel.

HIGGINSON, R. 1988. Dilemmas: a Christian Approach to Moral Decisionmaking. London : Hodder \& Stoughton.

JANSE VAN RENSBURG, J. 1991. 'n Kritiese ontleding van moralisme in die prediking. Bloemfontein : UOVS. (D.Th. - proefskrif.)

KAISER, W.C. 1983. Toward Old Testament Ethics. Grand Rapids : Zondervan.

KAMPHUIS, J. 1991. Godsvrucht - een kracht: antwoord aan de secularisatie. Goes : Oosterbaan \& Le Cointre. 
KEMP, S.G. 1992. Die perfeksionisme: 'n apologetiese en etiese studie. Potchefstroom : PU vir CHO. (Ph.D.-proefskrif.)

KUITERT, H.M. 1970. Anders gezegd: een verzameling theologische opstellen voor de welwillende lezer. Kampen : Kok.

KUTTERT, H.M. 1992. Het algemeen betwijfeld christelijk geloof. Baarn : Ten Have.

LAPIDE, P. 1984. Hoe heeft men zijn vijanden lief? Kampen : Kok.

NYGREN, A. 1952. Commentary on Romans. Translated by C.C. Rasmussen. London : SCM Press.

OVERDUIN, J. 1959. Ziet toe hoe gij hoort en ... preekt. (In Barkey Wolf, A.G. red. Hoe vind u dat er gepreekt moet worden? Zwolle : La Rivière \& Voorhoeve. p. 23-35.)

RIDDERBOS, H. 1959. Aan de Romeinen. Commentaar op het Nieuwe Testament. Kampen : Kok.

RIDDERBOS, H. 1966. Paulus: ontwerp van zijn theologie. Kampen : Kok. RIDDERBOS, H. 1992. Het evangelie naar Johannes - 2. Kampen : Kok. RIETVELD, B. 1968. Christelijke levensstijl. Kampen : Kok. ROTHUIZEN, G. Th. 1973. Wat is ethiek? Kampen : Kok.

SMEDES, L.B. 1992. Mere Morality: What God Expects from Ordinary People. Grand Rapids : Eerdmans.

STAM, C. 1950. De hemelvaart des Heren in de Godsopenbaring van het Nieuwe Testament. Kampen : Kok.

STOKER, H.G. 1941. Die grond van die sedelike. Stellenbosch : Pro Ecclesia. TROOST, A. 1958. Casuistiek en situasie-etiek. Utrecht : Drukkerij Libertas.

VAN DEN BERG, J. 1967? De wetsprediking in historisch perspectief. (In Van den Berg, J. et al. Die Thora in de Thora 1. Aalten : De Graafschap. p. 30-49.)

VAN DER WALT, S.P. 1971. Etiek - wetenskap van relasies. (In Bingle, H.J.J. et al. reds. Waarheid en werklikheid: wysgerige perspektiewe op die werklikheid opgedra aan prof. H.G. Stoker. Braamfontein : De Jong. p. 222-233.)

VAN GENDEREN, J. \& VELEMA, W.H. 1992. Beknopte Gereformeerde Dogmatiek. Kampen : Kok.

VAN WYK, J.H. 1983. Calvyn oor die Christelike lewe. Pretoria : N.G. Kerkboekhandel.

VAN WYK, J.H. 1986. Gesindheid en gestalte. Pretoria : N.G. Kerkboekhandel.

VAN WYK, J.H. 1991. Moraliteit en verantwoordelikheid: opstelle oor politieke etiek. Potchefstroom : PU vir CHO. Dept. Sentrale Publikasies.

VELEMA, W.H. 1987. Wet en evangelie. Kampen : Kok.

VELEMA, W.H. 1990. Oriëntatie in de christelijke ethiek. 's-Gravenhage : Boekencentrum.

VERKUYL, J. 1992. Die kern van het Christelijke geloof. Kampen : Kok. WIELENGA, B. 1947. Onze Catechismus 2. Kampen : Kok. 